\title{
An accurate digital restoration method based on architectural site information - A Case Study of the Jiujing Sanshi Hall in Changchun Garden
}

\author{
Ma Yinghua, Zhao Jiannan, Xu Bin \\ Tsinghua Heritage Institute for Digitization Company Limited, D-003, 3/F, Building 1, No.41 West Shangdi Road, Haidian District, \\ Beijing-zhaojiannan@thid.cn
}

KEY WORDS:architectural sites, accurate, digital restoration, classification, modelling, spatial information, dynamic adjustment

\begin{abstract}
:
Using records, documents, and research on Jiujing Sanshi Hall in Changchun Garden as an example, this paper showcases a method to digitally restore lost constructions to the maximum level of precision in their size, scale, architectural design, and structure using digital technology. The digital restoration can also be dynamically adjusted based on latest data. Information used to form such restorations include historical records, measurement data, and unknown data, which were then analyzed and recombined. This method fulfills the technical gap in high-precision digital restoration in China. The paper proposes an evaluation standard that involves "triple-evidence verification chain" and restoration accuracy, which can be used for most unmovable cultural relics, especially large ruins with few, scattered remains. The standard can provide a qualitative basis for the whole field of restoration research. The resulting restoration method is useful in cooperation and research between multiple cross-discipline organizations, as well as improving work effeciency and information sharing. Moreover, this restoration plan has integrated various virtual assembly methods and improved the integrity and authenticity of the site remains. It made breakthroughs in display methods of lost constructions and ruins such as enhanced showcasing of vanished ruins and changes over time. The plan also was able to enrich cultural connotation and existing contents of the ruins. The resulting restoration can be updated, and the information can be shared and used in open research.
\end{abstract}

\section{INTRODUCTION}

There are currently many organizations in the research and implementation digital restoration of cultural relics. Research organizations such as Dunhuang Academy, the Palace Museum, and Yungang Grottoes Research Institute have completed such projects, such as Digital Dunhuang, Digital Forbidden City, Digital Yungang. However, along with the production methods of the high-precision temporal restoration system of the Ming mausoleum belonging to the King of $\mathrm{Chu}$, and the 3D cultural remains restoration technique based on single-images, there exists a limitation: there is no research on what has already been lost. This limitation in the current restoration design and display significantly impacts the completeness of the content, and bars research on the changes over time and the construction techniques used. Hence, there is still room for improvement on the techniques for conveying the complete information of the site. Furthermore, these methods have not systematically organized and produced a comprehensive set of restoration research methodology, nor an evaluation system for the accuracy and precision of the restoration result. Additionally, the lack of one set standards and methods for digital restoration of simultaneously lost architectural relics makes it difficult for reasonable assessment of the accuracy of restoration results.

This paper will showcase how to use archival historical records, measurement data, and unknown data, analyzed and recombined to digitally restore lost constructions to the maximum level of precision in their size, scale, architectural design, and structure using digital technology based on Jiujing Sanshi Hall in Changchun Garden.

It explores a precise digital restoration method that can allow the public to learn more about the true information of the construction, based on historical records, limited archaelogical data, and analysis of similar constructions. 


\section{THE PRECISION DIGITAL RESTORATION SYSTEM}

\subsection{Modalization}

The pathway to modularization is as follows. First, collect data on currently existing contemporary construction categories. Next, organize a set of structural parameters based on the data to formulate modular data and modal range of values for reference. Lastly, complete the virtual digital restoration based on the range of the reference value and make fine adjustments based on known data.

The modular restoration design was based on the premise of reliable sources on the average values of modularized data matching, and the structural evidence from basic data modularization results. Such designs have strong data support, practical case support, and historical data support. The three kinds of data support formed in this restoration design were the strong "triple evidence" for effective pathways to unified modularization.

\begin{tabular}{|c|c|c|}
\hline Component Model & No.1 barrel tile & No.2 barrel tile \\
\hline $\begin{array}{l}\text { Reference data1 } \\
\text { Former Winter } \\
\text { Palace dimensions }\end{array}$ & 9" long & 7" long \\
\hline $\begin{array}{c}\text { Reference data } 1+1 \\
\text { Palace } \\
\text { archaeological } \\
\text { excavation } \\
\text { dimensions }\end{array}$ & $\begin{array}{l}\text { Length } 11 \\
\text { Width } 4.5\end{array}$ & \\
\hline $\begin{array}{l}\text { Reference data2 } \\
\text { Former Forbidden } \\
\text { City dimensi }\end{array}$ & 8" long & 7" long \\
\hline $\begin{array}{l}\text { Reference data3 } \\
\text { Typical official kiln } \\
\text { size }\end{array}$ & $\begin{array}{l}\text { Length } 11 \\
\text { Width } 4.5\end{array}$ & $\begin{array}{l}9.5^{\prime \prime} \text { long, } 3.8^{\prime \prime} \\
\text { wide }\end{array}$ \\
\hline $\begin{array}{c}\text { Reference } \\
\text { Value Grade Rating }\end{array}$ & \multicolumn{2}{|c|}{$\begin{array}{l}\text { Winter Palace is the closest in size and } \\
\text { construction techniques }\end{array}$} \\
\hline $\begin{array}{c}\text { Built } \\
\text { Modular data }\end{array}$ & $\begin{array}{l}\text { Length } 11 \\
\text { Width } 4.5\end{array}$ & $\begin{array}{l}\text { 9.5" long, 3.8" } \\
\text { wide }\end{array}$ \\
\hline
\end{tabular}

Table 1. Modulo analysis table

\subsection{TRIPLE EVIDENCE CHAIN}

Each segment of the evidence chain guarantees the completeness and authenticity of the information, as they can be used to co-verify one another. As each of the three segments was weighted differently, evaluation of information from each segment will be needed when there was conflict in the coverification. Primary and secondary data will also be compared to ensure data primacy and authenticity. Hence, this evaluation system can avoid subjective bias and ensure relative objective accuracy within its range of effectiveness of the final digitally restored model using the "triple evidence chain" . New research and archaelogical discoveries can also be used to support and verify the original model to further optimize the restoration model.
The process to completing a 3D high-precision restoration model is as follows: Organize and intake parameters with accurate data; clarify support data such as construction patterns of imperial gardens in Qing and Ming dynasties and examples of concurrent imperial gardens (Summer Palace, Digital Winter Palace, Jingming Garden); formulate triple-evidence chain information system; set up vector data and proof chain information tags for the 3D resource; start floating detection and verification of the restoration data valuation; carry out the verification of the evidence chain data; obtain high-precision restoration data; integrate clearly documented data parameters and restoration data; complete $3 \mathrm{D}$ high-precision restoration model.

After the model is completed, the following should be done using the same digital restoration technique: begin conversion of historical records and modularized concurrent data; collect and analyse work method data; complete the digitally restored model of Jiujing Sanshi Hall.

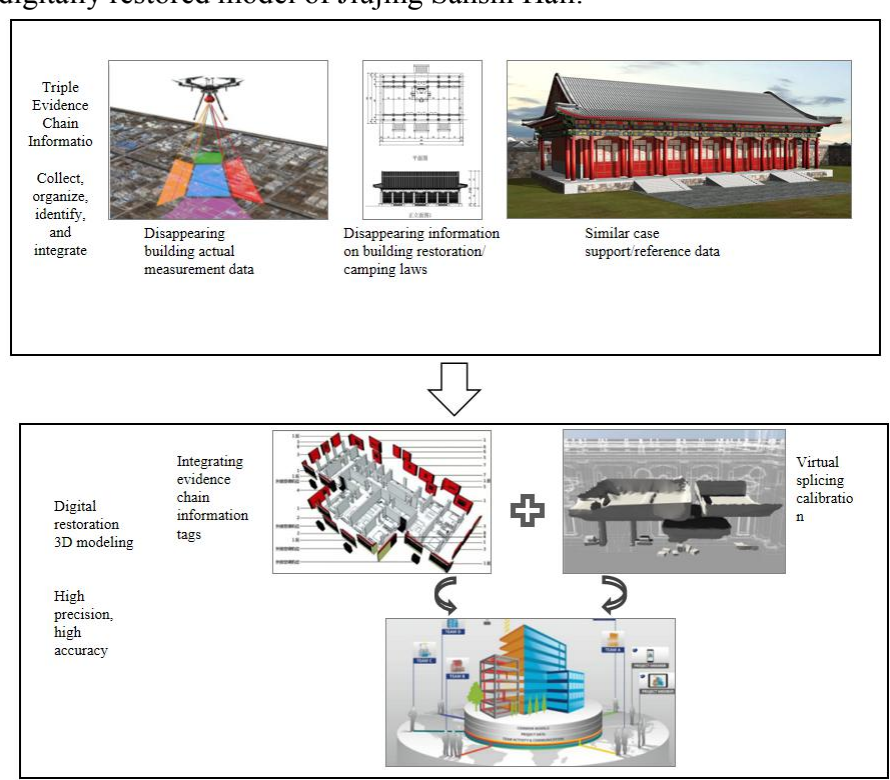

Figure1. Triple Evidence Identification

\subsection{ACCURACY ASSESSMENT}

There were two parts to designing the restoration. The first part was consisted of searching, summarizing, and comparing information from pieces of historical records and pictures, then compile the process of structural changes of the construction. The second part was doing detailed investigation, identification, and mapping of the ruins that can be turned into a complete document on the ruins; then the parts can be virtually assembled with 3D computer modelling. This can improve the accuracy and reliability of the restoration model.

When assessing the accuracy of the restoration, it is possible to use the standards to provide a quantitative accuracy rating based on the weight of the types of information. As each part of the model will receive an accuracy rating, it is possible to give a rating forthe overall $3 \mathrm{D}$ high-precision restoration model. This data can also be stored as a part of the information regarding the model, which can be updated as well. This will aid in developing AI rating and matching for future projects.

\begin{tabular}{|c|c|c|c|c|c|c|}
\hline \multicolumn{2}{|c|}{ Accuracy } & $100 \%$ & $90 \%$ & $75 \%$ & $50 \%$ & $15 \%$ \\
\hline $\begin{array}{l}\text { Desc } \\
\text { ptio }\end{array}$ & Size & $\begin{array}{c}\text { Complete } \\
\text { mastery }\end{array}$ & $\begin{array}{l}\text { Accu } \\
\text { rate } \\
\text { grasp }\end{array}$ & $\begin{array}{l}\text { Accur } \\
\text { ate } \\
\text { grasp }\end{array}$ & $\begin{array}{c}\text { Spec } \\
\text { ulati } \\
\text { on }\end{array}$ & $\begin{array}{c}\text { Spec } \\
\text { ulati } \\
\text { on }\end{array}$ \\
\hline
\end{tabular}




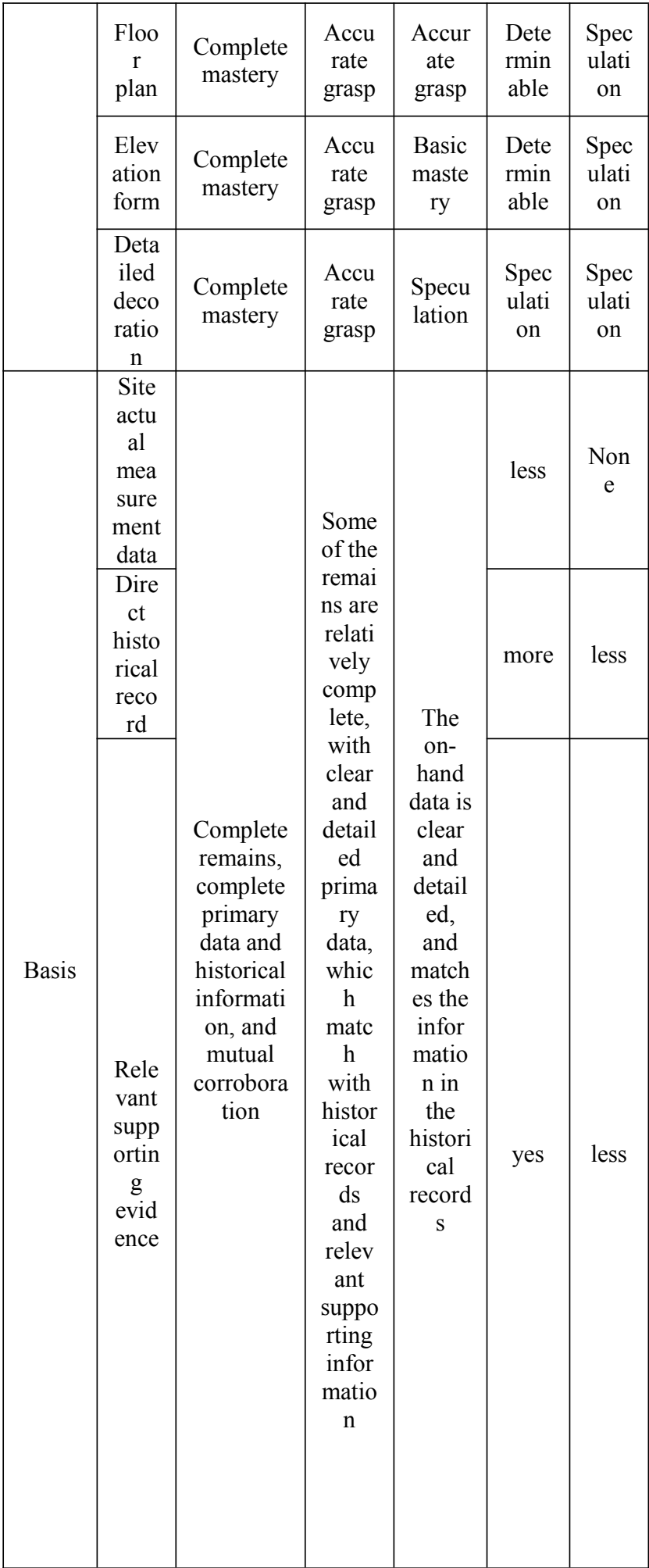

Table 2. Accuracy evaluation table

\section{TECHNIQUES AND METHODS}

\subsection{DATA COLLECTION}

3D scans, satellite imagery, research on historical layout, cloud model data on the site, sketches of the ruins site were used to collect data on the site. Written historical records, pictures (such as blueprints or design pictures), artistic depictions, primary historical data, construction patterns and rules (of concurrent constructions), existing constructions of similar type, and other historical records were used.

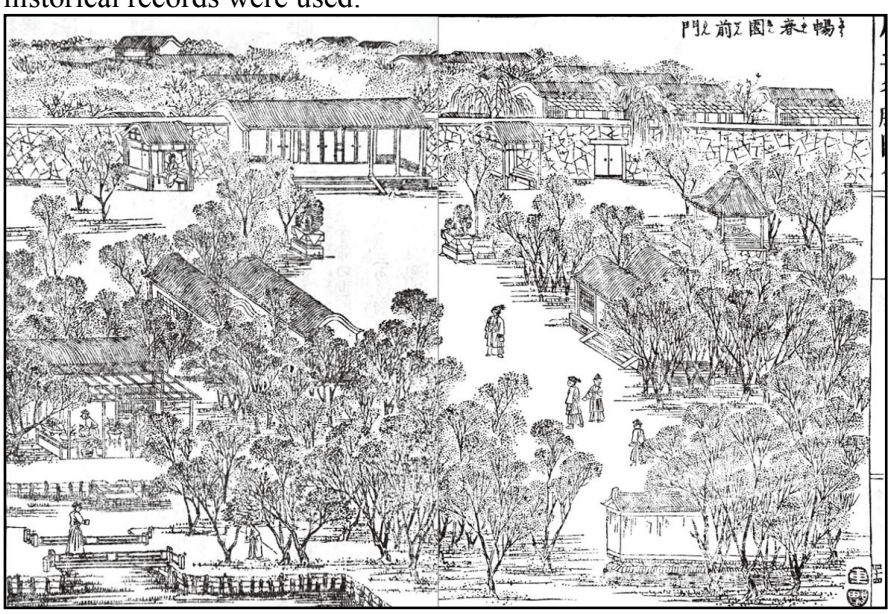

Figure 2 Artwork “Wanshou Shengdian”, where Jiujing Sanshi Hall is shown

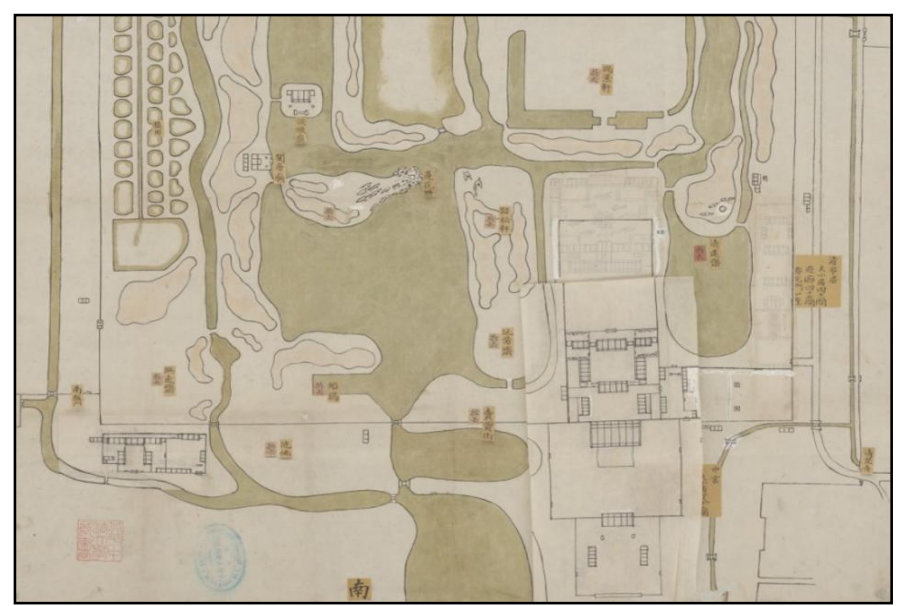

Figure 3 Full map of the Changchun Garden site - Jiujing Sanshi Hall (partial)

\subsection{BUILD DATABASE}

The collected data was categorized by method of collection and type of construction. The categorization was done as detailed and specific as possible; database was built based on the categories. Database has the following functions: storing and processing important data, editing, insertion, deletion, and updating the data charts. The database was used in value application and modularization.

Article 2189 in records of the House of Internal Affairs has shown the costs of building Changchun Garden: Kangxi Reign Year 52, on the 16th of the 6th month, Changchun Garden has received new hall with 7 rooms in front of its secondary gates; a total length of 10 zhang 3 chi, counting the corridor width of 6 zhang 2 chi, column height of 1 zhang 6 chi 50, will be built here 12 purlins, rolled shed, hills, ten corners, repair knotted brocade ceiling, partition, sill windows, horizontal phi, curtain frame, screen door, throne and other items. The stones of the pillar roof, steps, steep slabs, corner pillars, brick slabs and treads were made of green and white stone. The surrounding soil lining, dripping water, tooth, with green sandstone. The stone plinth was made of beanbag. Behind the steep board bar 
soil masonry old type city brick, filled with loess, outside with lime mixed with soil wipe two times. The floor with the city brick pavement layer, outside the burin brick. The mountain wall, the skirt shoulder of the mountain wall, the threshold wall inside and outside, with burin Qing brick dry masonry, with slurry filling. Above the skirt shoulder, outside with stop mud roller brick pulling system seam, inside with sand roller brick rough masonry, with lime mixed with earth to wipe it. The shed was glued with gorilla paper, thatched with lime mixed with earth, and paved with the first number of simple tiles and flat tiles. After planning the foundation, it was nailed with cypress wood ground nail piles, filled with sand roller bricks in the middle, and paved with beanbag stone outside.

\begin{tabular}{|c|c|c|c|c|}
\hline $\begin{array}{c}\text { Seri } \\
\text { al } \\
\text { nu } \\
\text { mb } \\
\text { er }\end{array}$ & Content & Data & $\begin{array}{c}\text { Data } \\
\text { Accounting }\end{array}$ & Remarks \\
\hline 1 & Room & $\begin{array}{l}\text { Seven } \\
\text { rooms in } \\
\text { the main } \\
\text { hall }\end{array}$ & $\begin{array}{l}\text { Horizontal } \\
\text { axis spacing } \\
950 \text { cun } \\
\text { Longitudina } \\
1 \text { axis } \\
\text { spacing } 528 \\
\text { cun }\end{array}$ & $\begin{array}{c}\text { Horizontal: 40- } \\
\text { 131-132-132- } \\
\text { 160-132-132- } \\
\text { 131-40 } \\
\text { Vertical: 46-60- } \\
\text { 348-60-60-46 }\end{array}$ \\
\hline 2 & $\begin{array}{l}\text { Total } \\
\text { length }\end{array}$ & $\begin{array}{l}10 \text { feet } \\
\text { by } 3 \text { feet }\end{array}$ & $\underset{34.2 \mathrm{~m}}{1030 \mathrm{cun}} \approx$ & $\begin{array}{c}131-132-132- \\
160-132-132-131\end{array}$ \\
\hline 3 & $\begin{array}{l}\text { Total } \\
\text { width }\end{array}$ & $\begin{array}{l}\text { The } \\
\text { width of } \\
\text { the } \\
\text { corridor } \\
\text { is } 6 \text { feet } \\
2 \text { feet }\end{array}$ & $\begin{array}{c}620 \mathrm{cun} \approx \\
20.58 \mathrm{~m}\end{array}$ & $\begin{array}{c}46-60-348-60- \\
60-46\end{array}$ \\
\hline 4 & $\begin{array}{c}\text { Column } \\
\text { height }\end{array}$ & $\begin{array}{l}\text { The } \\
\text { width of } \\
\text { the } \\
\text { corridor } \\
\text { is } 6 \text { feet } \\
2 \text { feet } \\
\end{array}$ & $\begin{array}{c}165 \mathrm{cun} \approx \\
5.48 \mathrm{~m}\end{array}$ & $\begin{array}{c}\text { Column } \phi 16 \\
\text { cun }\end{array}$ \\
\hline 5 & $\begin{array}{l}\text { Beam } \\
\text { frame }\end{array}$ & $\begin{array}{c}12 \\
\text { purlins }\end{array}$ & -- & Purl $\phi 11$ cun \\
\hline 6 & $\begin{array}{l}\text { Roof } \\
\text { form }\end{array}$ & $\begin{array}{l}\text { Scaffolde } \\
\text { d hillside }\end{array}$ & -- & - \\
\hline 7 & $\begin{array}{c}\text { Interior } \\
\text { Decorat } \\
\text { ion }\end{array}$ & $\begin{array}{l}\text { Screen } \\
\text { door, } \\
\text { throne, } \\
\text { partition }\end{array}$ & -- & North side row \\
\hline 8 & Tile & $\begin{array}{c}\text { First } \\
\text { number } \\
\text { of barrel } \\
\text { tiles }\end{array}$ & $\begin{array}{l}\text { Length } \\
11 \text { cun } \approx \\
365 \mathrm{~mm}\end{array}$ & -— \\
\hline
\end{tabular}

Table 3 Basic number precision table - Jiujing Sanshi Hall

\subsection{VALIDATION FORMULA MEASUREMENT}

Multiple evidence chains were calibrated, selected, and extrapolated for digital recovery data to improve and supplement the database content.
Specific calculation method.

Let the actual data be T: T1, T2, Tx ......Tn

The various types of evidence data were $\mathrm{R}$ :

Evidence chain A as RA:RA1, RA2, RAx......RAn

Evidence chain B was RB:RB1, RB2, RBx......RBn

Evidence chain $\mathrm{C}$ was $\mathrm{RC}: \mathrm{RC} 1, \mathrm{RC} 2, \mathrm{RCx} \ldots . . . \mathrm{RCn}$ tile size)

T1, RA1, RB1, RC1, for the same data (e.g., head number

$\mathrm{T} 2, \mathrm{RA} 2, \mathrm{RB} 2, \mathrm{RC} 2$, for the same data (e.g. tile size 2) and so on

Tx is the disappearing part that cannot be measured, RAx, $\mathrm{RBx}, \mathrm{RCx}$ were the known data

$\mathrm{R}-\mathrm{T}=\mathrm{M}$ is the error (error takes absolute value); $\mathrm{Mmax} / \mathrm{T}^{*} 100 \%=\mathrm{N}$ was the allowable floating range

$1-\mathrm{M} / \mathrm{T} * 100 \%=\mathrm{H}$ was the accuracy of single data

$(\mathrm{HA} 1+\mathrm{HA} 2+\mathrm{HA} 3+\ldots . .+\mathrm{HAn}) / \mathrm{n}=\mathrm{IA}$ was the confidence level of the evidence chain $A$ as a whole

If IA=Imax, then $T x=R A x$, and the data in plotting and modeling was $T x=R A x \pm R A x * N$ (to guarantee the rationality of plotting and modeling, the data can be up or down within the allowed range)

This method helps ensuring the application data and evidence chains (including construction rules) with high reliability could be used as the calculation basis for other unknown data.

\subsection{BUILDING THE DIGITAL RESTORATION MODEL}

Determine the overall frame and planar form $\rightarrow$ determine elevation form $\rightarrow$ determine decoration and other details $\rightarrow$ build restoration design' s floor plan $\rightarrow 3 \mathrm{D}$ modeling $\rightarrow$ scene integration.

Using editors, composite materials, and textures from 3ds Max and Material, the virtual model could be made with wellresearched materials and textures from existing constructions of the same type. Restoring the lost portions of the construction was the main focus of restoration. Trial and error based on recorded information was used to create a most reasonable depiction.

\subsection{VIRTUAL ASSEMBLY}

Identify and research existing parts to find their historical positions, either absolute or relative (parts that have apparent specificity and position were given absolute positions; parts that have apparent specificity but several possible positions were given relative positions). Modularize existing parts and assemble them to the 3D model; after comparing details such as color and texture, the high-precision 3D digital restoration model could then be completed.

We can summarize the steps based on the work from Jiujing Sanshi Hall as follows: (Technical innovations are described in detail; other common practices are described in brief)

(1) 3D scans, satellite imagery, research on historical layout, cloud model data on the site, sketches of the ruins site were used to collect data on the site. Written historical records, pictures (such as blueprints or design pictures), artistic depictions, primary historical data, construction patterns and rules (of concurrent constructions), existing constructions of similar type, and other historical records were used.

(2) The collected data was categorized by method of collection and type of construction. The categorization was done as detailed and specific as possible; database was built based on the categories. 
(3) By the method of multiple evidence chain projection, based on the existing measured data, the historical direct records and contemporaneous building rules were projected and selected to match to the best application position (by building category of data).

(4) Compare the direct historical records, match the construction rules, determine the scale and pattern of the original building, and draw a digital restoration master plan.

(5) Project the key dimensions of the restoration target by multiple evidence chain projection (key position shape or size ratio of the general shape of the building can be projected, and the key dimensions vary for different buildings and different historical periods)

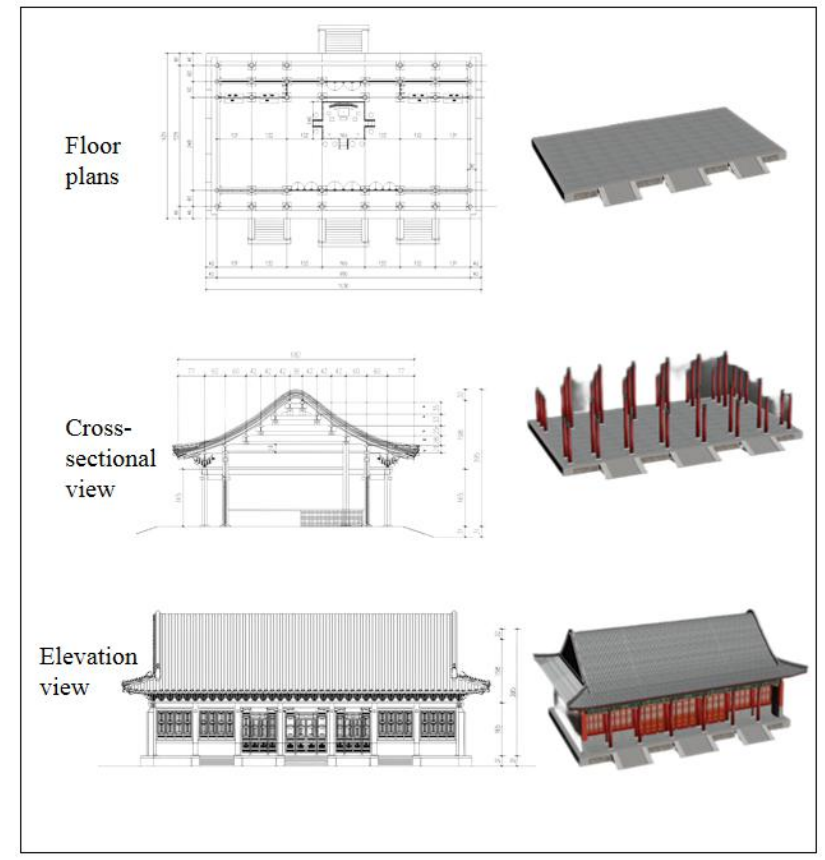

Figure 4. Diagram of the restoration process of the Jiujing Sanshi Hall

\section{SORT TECHNICAL RESULTS}

\subsection{RECOVERY PROCESS AND MODULIZATION}

Identify and research existing parts to find their historical positions, either absolute or relative (parts that have apparent specificity and position were given absolute positions; parts that have apparent specificity but several possible positions were given relative positions). Modularize existing parts and assemble them to the $3 \mathrm{D}$ model; after comparing details such as color and texture, the high-precision 3D digital restoration model could then be completed.

The dimensions of the tile were calculated: (Jiujing Sanshi Hall is a Qing Dynasty building, the key dimensions should be "column height", "width and depth of the face", "tile", related content involves key technical achievements, details therefore are not provided.)

Recorded reference data size T: T1 $(11,4.5), \mathrm{Tx}, \mathrm{T} 3(6,3.2), \mathrm{T} 3$ $(4,2.5)$

The size of the Winter Palace is RA, the size of the Forbidden City is RB, the regular size of the official kiln is RC

Calculation can be obtained: IA $=47 \%$, IB $=45.5 \%$, IC $=$ $93.75 \%$, then $\mathrm{Tx}(9.5,3.8)$, the floating range is $(7.13-$ $11.88,2.85-4.75)$; the data related to the components of the barrel tile projection focus on the case of the official kilns based on conventional building rules.

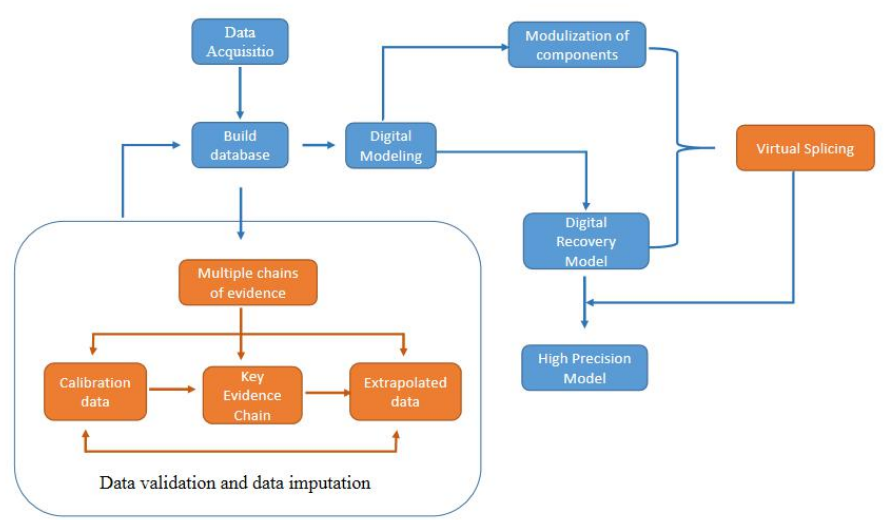

Figure 5. High-precision Digital Restoration Flow Chart

\subsection{DATA CLASSIFICATION REQUIREMENTS FOR RESTORATION RESULTS}

The data categorization of restoration results was mainly done by the follow method: Summarize the first-hand atmospheric data, direct historical records, and 3 categories of relevant circumstantial evidence; Lost building components were used as the basic data for categorization of result data. The main technical means include: Literature research, actual on-site measurement, scans, digital images, other media, actual objects, space, traditional techniques, construction methods, historical and cultural information related to the building components, environment, etc. These technical means can produce comprehensive and systematic organization. Through refined categorization, text editing, digital images, 3D virtual model, AutoCAD and other technical means, the digital restoration result data categorization was achieved.

\begin{tabular}{|c|c|c|c|}
\hline $\begin{array}{l}\text { Informati } \\
\text { on } \\
\text { Sources }\end{array}$ & \multicolumn{2}{|c|}{ Collection category } & $\begin{array}{l}\text { Architectur } \\
\text { al }\end{array}$ \\
\hline \multirow{6}{*}{$\begin{array}{l}\text { First- } \\
\text { hand data } \\
\text { (actual } \\
\text { site } \\
\text { survey } \\
\text { data) }\end{array}$} & \multirow{3}{*}{$\begin{array}{l}\text { Actual site } \\
\text { survey data }\end{array}$} & $\begin{array}{ll}\begin{array}{l}\text { Site } \\
\text { data }\end{array} & \text { ontology } \\
\end{array}$ & \multirow{8}{*}{$\begin{array}{l}\text { Orientation, } \\
\text { layout, } \\
\text { building as } \\
\text { a whole } \\
\text { (style, size, } \\
\text { scale, etc.), } \\
\text { building } \\
\text { components } \\
\text { (component } \\
\text { type, style, } \\
\text { size, scale, } \\
\text { etc. }\end{array}$} \\
\hline & & $\begin{array}{l}\text { Movable artifact } \\
\text { data related to } \\
\text { the creation of } \\
\text { the site proper }\end{array}$ & \\
\hline & & $\begin{array}{l}\text { Historic } \\
\text { environment } \\
\text { data (including } \\
\text { topographic } \\
\text { maps) }\end{array}$ & \\
\hline & \multirow{3}{*}{$\begin{array}{l}\text { Latest } \\
\text { archaeological } \\
\text { data } \\
\text { (archaeological } \\
\text { reports, } \\
\text { archaeological } \\
\text { mapping, } \\
\text { archaeological } \\
\text { records) }\end{array}$} & $\begin{array}{l}\text { Archaeological } \\
\text { excavation data }\end{array}$ & \\
\hline & & $\begin{array}{l}\text { Archaeological } \\
\text { exploration data }\end{array}$ & \\
\hline & & $\begin{array}{l}\text { Archaeological } \\
\text { survey data }\end{array}$ & \\
\hline \multirow{2}{*}{$\begin{array}{l}\text { Historica } \\
1 \text { direct } \\
\text { records } \\
\text { (direct }\end{array}$} & \multicolumn{2}{|l|}{ Textual History } & \\
\hline & \multicolumn{2}{|c|}{ Historical Archives } & \\
\hline
\end{tabular}




\begin{tabular}{|c|c|c|c|}
\hline $\begin{array}{l}\text { historical } \\
\text { record }\end{array}$ & \multicolumn{2}{|l|}{ Old Photos } & \\
\hline \multirow{4}{*}{$\begin{array}{l}\text { Relevant } \\
\text { circumsta } \\
\text { ntial } \\
\text { evidence } \\
\text { (contemp } \\
\text { oraneous } \\
\text { building } \\
\text { code } \\
\text { data)) }\end{array}$} & \multirow{2}{*}{$\begin{array}{l}\text { Similar } \\
\text { examples }\end{array}$} & $\begin{array}{l}\text { With physical } \\
\text { remains (also } \\
\text { involving } \\
\text { primary data) }\end{array}$ & \\
\hline & & $\begin{array}{l}\text { No physical } \\
\text { remains, but } \\
\text { direct historical } \\
\text { records }\end{array}$ & \\
\hline & $\begin{array}{l}\text { Reference } \\
\text { practices }\end{array}$ & Creation of laws & \\
\hline & History & $\begin{array}{l}\text { Written } \\
\text { historical } \\
\text { materials, } \\
\text { historical } \\
\text { documents, old } \\
\text { photographs } \\
\end{array}$ & \\
\hline $\begin{array}{l}\text { Informati } \\
\text { on } \\
\text { Sources }\end{array}$ & \multicolumn{2}{|c|}{ Collection category } & $\begin{array}{l}\text { Architectur } \\
\text { al } \\
\text { categories }\end{array}$ \\
\hline \multirow{6}{*}{$\begin{array}{l}\text { First- } \\
\text { hand data } \\
\text { (actual } \\
\text { site } \\
\text { survey } \\
\text { data) }\end{array}$} & \multirow{3}{*}{$\begin{array}{l}\text { Actual site } \\
\text { survey data }\end{array}$} & $\begin{array}{ll}\text { Site } & \text { ontology } \\
\text { data } & \\
\end{array}$ & \multirow{12}{*}{$\begin{array}{l}\text { Orientation, } \\
\text { layout, } \\
\text { building as } \\
\text { a whole } \\
\text { (style, size, } \\
\text { scale, etc.), } \\
\text { building } \\
\text { components } \\
\text { (component } \\
\text { type, style, } \\
\text { size, scale, } \\
\text { etc. }\end{array}$} \\
\hline & & $\begin{array}{l}\text { Movable artifact } \\
\text { data related to } \\
\text { the creation of } \\
\text { the site proper }\end{array}$ & \\
\hline & & $\begin{array}{l}\text { Historic } \\
\text { environment } \\
\text { data (including } \\
\text { topographic } \\
\text { maps) }\end{array}$ & \\
\hline & \multirow{3}{*}{$\begin{array}{l}\text { Latest } \\
\text { archaeological } \\
\text { data } \\
\text { (archaeological } \\
\text { reports, } \\
\text { archaeological } \\
\text { mapping, } \\
\text { archaeological } \\
\text { records) }\end{array}$} & $\begin{array}{l}\text { Archaeological } \\
\text { excavation data }\end{array}$ & \\
\hline & & $\begin{array}{l}\text { Archaeological } \\
\text { exploration data }\end{array}$ & \\
\hline & & $\begin{array}{l}\text { Archaeological } \\
\text { survey data }\end{array}$ & \\
\hline \multirow{3}{*}{$\begin{array}{l}\text { Historica } \\
1 \text { direct } \\
\text { records } \\
\text { (direct } \\
\text { historical } \\
\text { record } \\
\text { data) }\end{array}$} & \multicolumn{2}{|l|}{ Textual History } & \\
\hline & \multicolumn{2}{|c|}{ Historical Archives } & \\
\hline & \multicolumn{2}{|l|}{ Old Photos } & \\
\hline \multirow{3}{*}{$\begin{array}{l}\text { Relevant } \\
\text { circumsta } \\
\text { ntial } \\
\text { evidence } \\
\text { (contemp } \\
\text { oraneous } \\
\text { building } \\
\text { code } \\
\text { data)) }\end{array}$} & \multirow{2}{*}{$\begin{array}{l}\text { Similar } \\
\text { examples }\end{array}$} & $\begin{array}{l}\text { With physical } \\
\text { remains (also } \\
\text { involving } \\
\text { primary data) }\end{array}$ & \\
\hline & & $\begin{array}{l}\text { No physical } \\
\text { remains, but } \\
\text { direct historical } \\
\text { records }\end{array}$ & \\
\hline & $\begin{array}{l}\text { Reference } \\
\text { practices }\end{array}$ & Creation of laws & \\
\hline
\end{tabular}

\begin{tabular}{|l|l|l|l|}
\hline & History & $\begin{array}{l}\text { Written } \\
\text { historical } \\
\text { materials, } \\
\text { historical } \\
\text { documents, old } \\
\text { photographs }\end{array}$ & \\
\hline
\end{tabular}

Table4. Table of basic requirements for restoration results data

\section{CONCLUSION}

This digital restoration method is mainly for immovable cultural relics such as large sites and lost heritage buildings, to build a set of relatively systematic and scientific restoration research and verification methods, which can integrate relevant supporting materials and data, coordinate and standardize each workflow, maximize the authenticity and accuracy of restoration, recreate historical appearance, enhance site viewability, and recreate the experience of lost heritage site online.

\section{REFERENCES}

Digital reproduction of Yuanmingyuan Chapter 3: Guo Dai Chang Yan

Full translation of the Manchu zhengzhi of the Kangxi dynasty, edited by the First Historical Archives of China

Yuanmingyuan's - Memory Heritage - Stylistic Room Archives. Hou Houng Chang Guo, He Yan

China forbidden city society papers collection eighth series

Forbidden city style ray map - book 00004269 - sample 1324 changchunyuan ground situation full map

Kangxi period Changchun Garden plan layout speculation and its garden scenery name analysis. Cui Shan, Wang Qiheng, Cui Jingshu 